\title{
POTRET PRAKTIK AKUNTANSI UMKM MENGHADAPI VISIT SUMENEP 2018 (STUDI KASUS UMKM AL-IHSAN)
}

\author{
Irwan Didik Permana ${ }^{1}$, Djoko Nestri $\mathrm{K}^{2}$, Moh. Faisol ${ }^{3}$ \\ ${ }^{1,2,3)}$ Fakultas Ekonomi dan Bisnis Universitas Wiraraja \\ Email: irwandidikpermana@gmail.com
}

\begin{abstract}
ABSTRAK
Penelitian ini bertujuan untuk memahami praktek akuntansi pada UMKM serta peran praktek akuntansi UMKM dalam menghadapi Visit Sumenep 2018, yaitu UMKM AL-IHSAN, melalui metode penelitian kualitatif dengan pendekatan fenomenologi. Dimana ditemukan 2 bentuk praktik akuntansi yaitu biaya produksi serta packaging, upah pekerja dan menentukan harga jual sesuai dengan keinginan pemilik UMKM AL-IHSAN. Lebih lanjut, praktik akuntansi belum dimanfaatkan sebagai dasar pengambilan keputusan usaha, namun hanya dimanfaatkan sebagai control atas kegiatan usaha dan sumber informasi biaya produk, harga jual dan laba usaha. Pengambilan keputusan usaha belum dilakukan secara rasional, melainkan berdasarkan instuisi pemilik berdasarkan pengalaman serta kesanggupan pekerja. Temuan penelitian diatas menunjukkan praktik akuntansi pada UMKM AL-IHSAN masih rendah, serta UMKM Al-IHSAN pada praktek akuntansinya belum memiliki peran terhadap Visit Sumenep 2018.
\end{abstract}

Kata kunci: Potret Akuntansi UMKM

\section{INTRODUCTION}

Latar belakang penelitian ini terkait dengan pengamatan peneliti atas semakin berkembangnya Usaha Mikro Kecil Menengah (UMKM) di Indonesia. Perkembangan ini dapat dilihat dari kontribusi UMKM yang lebih besar terhadap perekonomian di Indonesia jika dibandingkan dengan perusahaan berskala besar. Kontribusi UMKM dapat dilihat dari prosentasi jumlah unit usaha UMKM yang mencapai 99.99\% per tahun, kemampuan memberikan kesempatan kerja yang menunjukkan angka hingga $97 \%$ pertahun, dan sumbangan signifikan terhadap produk domestik bruto (PDB) yang menunjukkan lebih dari 55\% setiap tahunnya (depkop, 2010-2012., dan Bps.2012). Tantangan utama yang dihadapi oleh pelaku UMKM adalah pengelolaan dana. Pengelolaan dana yang baik merupakan faktor penting yang menyebabkan berhasil atau tidaknya UMKM tersebut.

Terkait dengan kondisi ini, untuk mempermudah UMKM dalam penyusunan laporan keuangan maka pada tahun 2009, Dewan Standar Akuntansi Keuangan (DSAK) telah mensahkan SAK ETAP dan standar ini berlaku efektif per 1 Januari 2011 Adanya SAK ETAP diharapkan kedepannya UMKM bisa melakukan pencatatan akuntansi yang baik untuk menyajikan laporan keuangan yang informatif.

Meskipun hal ini bertujuan mempermudah UMKM, namun pada praktiknya di Sumenep sendiri masih banyak pelaku UMKM tidak menggunakan informasi akuntansi dalam mengolah usahanya. Hal ini dikarenakan pelaku UMKM menganggap proses akuntansi tidak terlalu penting atau dipandang sebelah mata untuk diterapkan sehingga praktik akuntansi yang diterapkan 
UKM umumnya sangat sederhana dan cenderung mengabaikan kaidah pencatatan akuntansi yang standar. Hal ini juga berdampak pada pasang surutnya UKM di Sumenep, karena mereka hanya menganggap usahanya sekedar untuk makan sehari-hari.

Pada fenomena "Visit Sumenep 2018 “ ini, harus dimanfaatkan sebaik mungkin bagi para pelaku UMKM di kabupaten Sumenep. Selain daya jual yang meningkat, juga dapat memperkerjakan masyarakat sekitar daerah wisata untuk memetik kekeuntungan dari adanya pariwisata tersebut. Para wisatawan juga pasti membeli oleh-oleh khas dari tempat yang dikunjungi. Selain daya jual yang meningkat, juga dapat memperkerjakan masyarakat sekitar daerah wisata untuk memetik kekeuntungan dari adanya pariwisata tersebut. Para wisatawan juga pasti ingin membeli buah tangan khas dari tempat yang dikunjungi.

Penilitian ini memilih pada salah satu UMKM di Kabupaten Sumenep yang telah menjadi unggulan di Kabupaten Sumenep sebagai informan penelitiannya. UMKM AL IHSAN mempunyai produk yang unik berbahan dasar laos juga menjadi salah satu alasan peniliti melakukan penilitiannya. Alasan peneliti menggunakan studi kasus pada salah satu UMKM unggulan di Kabupaten Sumenep karena peniliti mengaggap UMKM yang sudah menjadi unggulan berarti UMKM itu telah berkembang pesat dan berhasil dalam menjalankan usahanya. UMKM ini memproduksi kopi dan abon dari laos. Hal unik ini juga yang mendasari peneliti memilih UMKM AL IHSAN.

\section{LITERATURE REVIEW Usaha Mikro, Kecil dan Menengah}

Menurut Undang-Undang Republik Indonesia nomor 20 tahun 2008 tentang Usaha Mikro, Kecil dan Menengah pada bab 1 pasal 1 menerangkan bahwa yang dimaksud dengan:

a. Usaha Mikro

Usaha mikro adalah usaha produktif milik orang perorangan dan/atau badan usaha perorangan yang memenuhi kriteria Usaha Mikro sebagaimana diatur dalam UndangUndang ini.

b. Usaha kecil

Usaha Kecil adalah usaha ekonomi produktif yang berdiri sendiri, yang dilakukan oleh orang perorangan atau badan usaha yang bukan merupakan anak perusahaan atau bukan cabang perusahaan yang dimiliki, dikuasai, atau menjadi bagian baik langsung maupun tidak langsung dari usaha menengah atau usaha besar yang memenuhi kriteria usaha kecil sebagaimana dimaksud dalam undangundang.

c. Usaha menengah

Usaha Menengah adalah usaha ekonomi produktif yang berdiri sendiri, yang dilakukan oleh orang perorangan atau badan usaha yang bukan merupakan anak perusahaan atau cabang perusahaan yang dimiliki, dikuasai, atau menjadi bagian baik langsung maupun tidak langsung dengan Usaha Kecil atau Usaha Besar dengan jumlah kekayaan bersih atau hasil penjualan tahunan sebagaimana diatur dalam Undang-Undang ini.

\section{Laporan Keuangan}

Laporan keuangan merupakan ringkasan dari suatu proses pencatatan dan ringkasan dari transaksi-transaksi keuangan yang terjadi selama tahun buku yang 
bersangkutan.Pernyataan Standar Akuntansi Keuangan (PSAK) No. 1 menjelaskan bahwa tujuan laporan keuangan adalah menyediakan informasi yang menyangkut posisi keuangan, kinerja, serta perubahan posisi keuangan suatu perusahaan yang bermanfaat bagi sejumlah besar pemakai dalam pengambilan keputusan.

Urutan laporan keuangan berdasarkan proses penyajiannya adalah :

1) Laporan Laba Rugi (Income Statement) merupakan laporan yang sistematis tentang pendapatan dan beban perusahaan untuk satu periode waktu tertentu. Laporan laba rugi ini akhirnya memuat informasi mengenai hasil usaha perusahaan, yaitu laba atau rugi bersih yang merupakan hasil dari pendapatan dikurangi beban.

2) Laporan Modal Pemilik (Statement of Owner's Equity) adalah sebuah laporan yang menyajikan ikhtisar perubahan dalam modal pemilik suatu perusahaan untuk satu periode waktu tertentu (Laporan Perubahan Modal). Modal pemilik akan bertambah dengan adanya investasi (Setoran Modal) dan laba bersih, sebaliknya modal pemilik akan berkurang dengan adanya prive (penarikan/pengambilan uang tunai untuk kepentingan pribadi pemilik) dan rugi bersih. Pada perusahaan perseroan (Coorporation), Laporan laba ditahan (retained earnings statement) dibuat untuk menyajikan ikhtisar peruabahan dalam saldo laba ditahan. Dividen kas maupun dividen saham yang diumumkan sepanjang periode akan mengurangi besarnya saldo laba ditahan.

3) Neraca (Balance Sheet) adalah sebuah laporan yang sistematis tentang posisi aktiva, kewajiban, dan modal perusahaan per tanggal tertentu. Tujuan neraca adalah untuk menggambarkan posisi keuangan perusahaan.
4) Laporan Arus Kas (Statement of Cash Flow) adalah sebuah laporan yang menggambarkan arus kas masuk dan arus kas keluar secara terperinci dari masingmasing aktivitas, mulai dari aktivitas operasi, aktivitas investasi, sampai pada aktivitas pendanaan (pembiayaan) untuk satu periode waktu tertentu. Laporan arus kas menunjukkan besarnya kenaikan dan penurunan bersih kas dari seluruh aktivitas selama periode berjalan serta saldo kas yang dimiliki perusahaan sampai dengan akhir periode.

5) Catatan atas Laporan Keuangan (Notes to The Financial Statement) merupakan bagian integral (satu kesatuan) yang tidak dapat dipisahkan dari komponen laporan keuangan lainnya. Tujuan catatan ini adalah untuk memberikan penjelasan yang lebih lengkap mengenai informasi yang disajikan dalam laporan keuangan.

Penyusunan laporan keuangan dilakukan secara periodik dan periode yang biasa digunakan adalah tahunan yang mulai 1 Januari dan berakhir dan berakhir pada tanggal 31 Desember. Periode seperti ini disebut periode tahun kalender. Selain tahun kalender, periode akuntansi bisa juga dimulai dari tanggal selain tanggal 1 Januari. Istilah periode akuntansi sering juga disebut dengan istilah tahun buku.

\section{SAK ETAP}

SAK ETAP adalah Standar Akuntansi Keuangan untuk Entitas Tanpa Akuntabilitas Publik, artinya SAK ETAP diperuntukkan bagi entitas yang laporan keuangannya tidak akuntabel untuk publik secara luas. Biasanya SAK ETAP diterapkan oleh usaha kecil dan menengah, karena tidak memperjualbelikan sahamnya di pasar modal. SAK ETAP diterbitkan tahun 2009 berlaku efektif 1 Januari 2011 dan dapat diterapkan 
lebih awal yaitu 1 Januari 2010. SAK ETAP ini dimaksudkan agar semua unit usaha menyusun laporan keuangan sesuai dengan standar yang telah ditetapkan.

Sesuai dengan ruang lingkup SAK ETAP maka Standar ini dimaksudkan untuk digunakan oleh entitas tanpa akuntabilitas publik. Entitas tanpa akuntabilitas publik yang dimaksud adalah entitas yang tidak memiliki akuntabilitas publik signifikan; dan tidak menerbitkan laporan keuangan untuk tujuan umum (general purpose financial statement) bagi pengguna eksternal.

Menurut Ikatan Akuntan Indonesia dalam SAK ETAP (2009), laporan keuangan adalah bagian dari proses pelaporan keuangan, dan laporan keuangan yang lengkap meliputi : neraca, laporan laba rugi, laporan perubahan modal, laporan arus kas, dan catatan atas laporan keuangan.

\section{METHODS}

Jenis penelitian yang digunakan adalah penelitian kualitatif interpretatif dengan pendekatan fenomenologi. Sumber data yang digunakan merupakan data primer yang berbentuk kualitatif berupa dokumen dan catatan dari jawaban hasil wawancara dengan responden seputar praktik akuntansi UMKM AL IHSAN. Teknik Pengumpulan data dalam penelitian ini yaitu, observasi langsung pada objek. Pada observasi ini, peneliti datang langsung kepada objek untuk mengetahui praktik akuntansi yang dilakukan pada objek penelitian di UMKM AL IHSAN. Wawancara, peneliti melakukan wawancara dengan sumber-sumber informan yang dianggap berkaitan denga penelitian ini seperti pemilik UMKM, bagian keuangan, bagian produksi serta bagian marketing, hal itu dilakukan agar mendapatkan informasi yang mendalam. Teknik-teknik wawancara yang dipakai pada penelitian ini ialah dengan wawancara terbuka serta tidak terstruktur, penulis akan bertanya seputar bagaimana pelaksanaan pencatatan akuntansi yang dijalankan oleh objek penelitian. Serta dokumentasi yangberupa foto, rekaman, dan dokumen-dokumen laporan keuangan serta nota-nota.

Teknik analisis data untuk menganalisis data yang diperoleh yaitu Reduksi data, dimana peneliti merangkum dan memilih informasi inti yang sesuai dengan fokus penelitian. Pemilihan dan perangkuman data dilakukan apabila data yang diperoleh dari narasumber terlalu banyak dan takutnya tidak semua relevan dengan rumusan masalah. Penyajian data yang dilakukan dalam bentuk uraian singkat sehingga dapat memudahkan peneliti untuk memahami kondisi yang terjadi dan dapat menentukan tahap selanjutnya. Penarikan kesimpulan dan verifikasi. Dalam tahap ini penulis akan menarik sebuah kesimpulan dari berbagai data-data yang sudah didapat dan juga diolah sebelumnya sehingga bisa ditemukan sebuah kesimpulan yang apik terkait dengan penelitian ini dengan berdasarkan data yang valid dari lapangan.

\section{RESULTS AND DISCUSSIONS Praktik Akuntansi Pada UMKM Al-Ihsan}

Praktik akuntansi yang diselenggarakan oleh UMKM AL-IHSAN dalam menentukan biaya produksi dilakukan apabila terdapat pesanan. Pada UMKM AL-IHSAN upah pekerja sudah ditentukan oleh saudara Ulfa, tetapi ada beberapa faktor yang bukan dari penentuan jumlah upah tiap pekerja. Sebagaimana disampaikan oleh saudara Ulfa:

"Kadang iya itu sereh atau kayu manis di kasih sama pekerja di sini secara cumacuma. Nah itu yang dikasih kasih kadang gak dicatat. Saya ya sungkan, wong kita jualan masak gak di kasih. Jadinya saya kadang kasih upah lebih kalau pas 
produksi itu, biasanya upahnya 20.000/pesanan ini jadi 35.000 sampai 40.000/pesanan untuk hanya beberapa sereh sama itu kayu manis. Itung-itung sedekah gitu ya ...."

Dari pernyataan di atas, dapat dijelaskan bahwa upah pekerja terkadang tidak menentu. Dikarenakan ada beberapa pekerja yang terkadang memberi bahan baku untuk kopi laos secara cuma-cuma. Pemilik UMKM ALIHSAN pun terkadang memberikan upah lebih pada pekerjanya karena pemberian bahan baku secara sukarela. Di dalam pernyataan saudara Ulfa juga dapat dilihat bahwa upah pekerja langsung dibayarkan berdasarkan pesanan yang sudah diselesaikan proses pengerjaannya. Meskipun upah pekerja di sini dihitung perhari. Pada konteks upah pekerja per pesanan diatas dimaksudkan pada jumlah hari selesai pengerjaan satu pesanan yang sudah diselesaikan.

Kendala pada proses packaging ini ialah pada minimal order pouch itu sendiri. Sesuai dengan pernyataan dari saudara Ulfa :

“ wah packaging di kita sudah bagus mas, tapi kita itu gini mas...minimal pesannya 1000pcs. Tiap itu kenanya 6000. Juga ini mas, kita gak masukkan biaya ongkos kirim packaging-nya. Jadinya itu nggak kecatet. Tapi untungnya ngirim dari Surabaya, jadinya gak terlalu mahal. Tapi awal tahun kemaren itu, kita cuman 500pcs yang dibawa sendiri pas ke Surabaya itu, jadi dibawa sekalian. Sisanya dikirim pake J\&T."

Pernyataan di atas menjelaskan bahwa harga satuan packaging pouch sudah ketahuan dari pihak supplier. Pihak UMKM ALIHSAN hanya mengetahui harga satuan packaging tetapi tidak memperhatikan ongkos kirim sebagai salah satu faktor penentu harga produksi kopi laos. UMKM AL-IHSAN tidak berdasarkan penentuan biaya produksi. Melainkan pihak UMKM AL-IHSAN hanya sekedar mengetahui biaya produksi saja. Sedangkan menentukan harga jual, berpatokan pada keunggulan produknya. Dari segi keunikannya yaitu berbahan dasar laos, produk asli Madura, khasiat dari laos itu sendiri lalu packagingmodern yang sudah siap bersaing di pasar tingkat nasional.

Bentuk praktik akuntansi yang dilakukan UMKM AL-IHSAN dalam kegiatan pencatatan dan pengumpulan bukti pembayaran masih dilakukan dengan cara sederhana sebagaimana dijelaskan oleh saudara Ulfa:

“ oh kalau masalah bukti-bukti itu mas, kadang gini kejadiannya...kita ada pesanan gitu atau ada pameran yang di adakan di daerah, kita catat dulu keperluannya apa. Lalu beli bahan-bahan kayak gula, kopi gitu. Nah...kalau sudah beli bahan-bahan, di total tuh belinya habis berapa. Udah itu totalnya kita tulis untuk pesanan si A. Udah gitu aja mas."

$\begin{array}{lrrr}\text { Walaupun } & \text { UMKM } & \text { AL-IHSAN } & \text { sudah } \\ \text { melakukan } & \text { kegiatan } & \text { mencatat } & \text { dan }\end{array}$ mengumpulkan bukti transaksi, namun tidak selalu dua kegiatan ini selalu diterapkan. Kegiatan mencatat ala kadarnya juga dilakukan UMKM AL-IHSAN pada saat bebelanja bahan-bahan kopi laos. Berdasarkan hasil wawancara, pengamatan, dan pengumpulan bukti transaksi dapat dilihat bahwa praktik akuntansi berupa kegiatan mencatat dan mengumpulkan bukti transaksi belum dilakukan secara rapi dan tertib. Bahkan bukti penjualan kopi laos yang merupakan produk unggulan UMKM ALIHSAN tidak dicatat secara rutin. 


\section{Peran Praktik Akuntansi UMKM}

\section{Al-IHSAN dalam Menghadapi "Visit Sumenep 2018"}

Selama melakukan wawancara, peneliti menemukan peran akuntansi pada UMKM AL-IHSAN hanya sebatas pada strategi pemasaran saja. Meskipun pada pengalaman penulis bahwasanya mengikuti event-event atau pameran di Kabupaten Sumenep mengeluarkan biaya-biaya seperti upah penjaga stand dan biaya ongkos kirim meskipun hanya menggunakan fasilitas pribadi pemilik usaha. Sebagaimana pernyataan saudari Ulfa dan saudara Gusti :

" kalau ikut kayak acara acara itu mas, kita kan bawa angkut barang dagangan kita ke tempat pake mobil pribadi. Itu gak kehitung mas bensinnya, trus kan yang jaga kan pasti ada. Itu gak kehitung bejerenna. Ya gimana ya,...aku kan ikut dalam usaha ini jadi terro kiya waoreng laen tao. Jadi gregetan sendiri, pengen maju nih usaha dan dikenal banyak orang. Jadi ya itu mas balek lagi ke biaya ini itu gak kehitung. Kalau tenda kayak stand itu kan dari sananya."

"kita juga pengen mas kayak nota-nota yang hilang itu disimpen rapi, biar tau dapetnya berapa bersihnya. Tapi susah...nyimpennya. Kayak gak perfect gitu kalau sudah nyampe rumah. Tautaunya dapet segitu. Tapi ya alhamdulillah masih untung."

Dilanjut dengan pernyataan saudara Gusti:

"saya kalau ikut pameran itu kan pengennya produk kita jadi sorotan dan keberadaannya diakui oleh masyakat Sumenep, bukan hanya masyarakat luar aja. Produk kita ini harus meyakinkan pengunjung kalau kita asli kopi laos Madura. Jadi kadang saya kasih banner gitu, ada tulisan Asli Madura. Banner itu kan buat, meskipun 50.000 an lah anggap, itu kalau di akuntansi kan dicatat apalagi ini usaha rumahan. Kalau sudah sampe rumah ya gak masuk hitungan udah."

Pada dasarnya pengelola UMKM AL-IHSAN menginginkan pencatatan akuntansi yang lengkap dan tepat sesuai dengan ketentuan yang berlaku umum maupun khusus sesuai dengan aturan UMKM yang ada. Hanya saja saat ini kurang adanya perhatian untuk pelatihan maupun SDM yang kurang memadai yang ada di UMKM AL-IHSAN.

Peneliti menemukan bahwa pada UMKM AL-IHSAN tidak adanya peran pemerintah dalam mengembangkan SDM terutama dari segi kegiatan akuntansi. Hal ini sejalan dengan dengan pernyataan saudari ulfa yang menyatakan sebagai berikut:

"kalo dipelajari akuntansi, untuk usaha UMKM khususnya menunjang Visit Sumenep kayaknya ga pernah mas. Tapi kalo sebelumnya-sebelumnya mungkin diterima oleh mbak Yuni, karna dia kan banyak temannya disana"

Dari pernyataan diatas dapat dikatakan peran pemerintah dalam kegiatan pelatihan akuntansi untuk menunjang "Visit Sumenep 2018" khususnya UMKM tidak pernah direalisasikan dengan baik

\section{CONCLUSIONS}

Berdasarkan hasil penelitian yang dilakukan oleh peneliti, maka peneliti dapat menyimpulkan bahwa bentuk praktik akuntansi dari UMKM AL-IHSAN secara garis besar, terdapat dua bentuk praktik akuntansi yang diterapkan oleh UMKM AlIHSAN. Pertama, kegiatan biaya produksi berdasarkan pesanan dan harga jual produk. Pada kegiatan menentukan biaya produksi terdapat 3 komponen yaitu biaya bahan baku, 
upah pekerja dan packaging. Menentukan harga jualnya juga sesuai keinginan dari informan. Kedua, kegiatan mencatat dan mengumpulkan bukti transaksi, dimana UMKM Al-IHSAN hanya menerapkan ala kadarnya dan belum menerapkan secara rutin dan lengkap pada setiap kegiatan mencatat ataupun transaksi.

Peran praktik akuntansi UMKM ALIHSAN dalam menghadapi "Visit Sumenep 2018" tidak memiliki peran yang signifikan dari pihak Pemkab Sumenep . Dimana UMKM AL-IHSAN hanya memaknai "Visit Sumenep" dengan memanfaatkan strategi pemasaran produknya untuk lebih dikenal masyarakat Sumenep bahwa kopi laos ini hasil olahan yang asli Madura. Pada prakik akuntansi pun tidak maksimal, sebagaimana yang sudah di jelaskan di bab sebelumnya. Pihak pemerintah juga tidak mengadakan khusus untuk pelatihan akuntansi pada UMKM khususnya untuk membantu usahanyamenghadapi “ Visit Sumenep 2018 “. Biaya promosi pada saat pameran tidak terhitung dan tercatat, meskipun dari pihak UMKM AL-IHSAN sendiri ingin menyempurnakannya dengan mencatat dan menyimpan bukti-bukti biaya promosi sebagai tolak ukur profit yang didapat selama mengikuti pameran dan even-even yang salah satunya ikut mensukseskan "Visit Sumenep 2018 “. Pemerintah hanya terfokus pada potensi alam dan kebudayaan Kabupaten Sumenep.

\section{REFERENCES}

Alters dan Van Mark . 2004. Jurnal Ekonomi Pembangunan. Vol 9 (2) dan Hal 143164.

Danang Yudhiantoro, dan Eny Endah P. 2015. UKM Sebagai Komponen Pengembangan Desa yang
Berkelanjutan. The $2^{\text {nd }}$ University Research Coloquium.

Data UKM POKMAS APP A-IHSAN Kab. Sumenep Tahun 2017.

Juhanda Apryanto, Siti Khairani, dan Raisa Pratiwa. 2014. Analisis Penerapan Akuntansi Berdasarkan SAK ETAP pada UMKM (Studi Kasus pada Pengusaha Budidaya Lele Mariani). SAK ETAP Financial Report.

Lilya Andriani, Anantawikrama Tungga A, dan Ni Kadek S. 2014. Analisis Penerapan Pencatatan Keuangan Berbasis SAK ETAP pada UMKM (Studi Interpretatif pada Peggy Salon). e-Journal S1 Akuntansi Vol 2 (1).

RENSTRA DISPARBUDPORA Kab. Sumenep Tahun 2018-2021.

Rian Destiningsih, dan Andhatu Achsa. 2017. Potret Usaha Mikro dalam Menyongsong Desa Wisata Balesari "Nol Kilometer Jawa". Eko-Regional Vol. 12 (1).

UU RI No. 20 Tahun 2008 Bab I pasal 1 tentang Usaha Mikro, Kecil dan Menengah.

UU RI No. 20 Tahun 2008 Bab II pasal 2 tentang Usaha Mikro, Kecil dan Menengah.

UU RI No. 20 Tahun 2008 Bab IV pasal 6 tentang Usaha Mikro, Kecil dan Menengah.

Verniaputri A, M Khalid Mawardi, dan Edriana Pangestu. 2016. Strategi Pengembangab UMKM untuk Meningkatkan Citra Kota Malang Sebagai Destinasi Wisata Kuliner (Studi pada UKM Berbasis Kuliner Kota Malang). Jurnal Administrasi bisnis. Vol 38 (2). 